\title{
Synthesis and Crystal Structure of the Bis( $\mu$-hydroxo)diiron(II) Complex with Tridentate Ligands Having a Sterically Bulky Imidazolyl Group
}

\author{
Reiko YAgUCHI, ${ }^{* 1}$ Hideki FurUtaChI, ${ }^{* 1 \dagger}$ Sanae ShIrotsuki, ${ }^{* 1}$ Xi Zhang, ${ }^{* 1}$ Takanao IshIKawa, ${ }^{* 1}$ \\ Shigehisa AKINE, ${ }^{* 1, * 2}$ Takehiko Tosha, ${ }^{* 3}$ Shuhei FuJINAMI, ${ }^{* 1}$ Masatatsu SuZUKI, ${ }^{* 1}$ and \\ Teizo KitagaWA*4 \\ *1 Department of Chemistry, Division of Material Sciences, Graduate School of Natural Science and Technology, \\ Kanazawa University, Kakuma-machi, Kanazawa 920-1192, Japan \\ *2 Nano Life Science Institute (WPI-NanoLSI), Kanazawa University, Kakuma-machi, Kanazawa 920-1192, Japan \\ *3 Biometal Science Laboratory, RIKEN SPring-8 Center, Kouto, Sayo, Hyogo 679-5148, Japan \\ *4 Picobiology Institute, Graduate School of Life Science, University of Hyogo, Ako-gun, Hyogo 678-1297, Japan
}

\begin{abstract}
The structure of the dinuclear Fe(II) complex $\left[\mathrm{Fe}_{2}(\mathrm{OH})_{2}(\mathrm{~L})_{2}\right]\left(\mathrm{ClO}_{4}\right)_{2}(\mathbf{1})$ was determined by X-ray crystallography, where $\mathrm{L}$ is bis(1-methyl-2-phenyl-4-imidazolylmethyl)benzylamine. The compound crystallizes in a monoclinic space group, $P \overline{1}$, with $a=11.007(2), \quad b=11.5591(12), c=12.534(2) \AA, \quad \alpha=63.254(12), \beta=86.458(19), \quad \gamma=79.581(7)^{\circ}, Z=1$, $V=1400.4(4) \AA^{3}$. The $R 1[I>2 \sigma(I)]$ and $w R 2$ (all data) values are 0.00328 and 0.0862 , respectively, for all 6735 independent reflections. The complex has a bis( $\mu$-hydroxo)diiron core structure.
\end{abstract}

(Received December 26, 2018; January 10, 2019; Published on web May 10, 2019)

The $\mathrm{Fe}_{2} / \mathrm{O}_{2}$-mediated arene hydroxylation is of current interest for understanding the reaction mechanism of a dioxygen activating non-heme dinuclear iron enzyme, such as toluene monooxygenase (TMO). ${ }^{1-3} \quad$ Previously, we reported on intramolecular aromatic ligand hydroxylation via the decay of ( $\mu$-peroxo)diiron(III) complexes with the dinucleating ligands having a phenyl group as a reaction probe..$^{4-6}$ In this study, we synthesized the bis $\left(\mu\right.$-hydroxo)diiron(II) complex $\left[\mathrm{Fe}_{2}(\mathrm{OH})_{2}(\mathrm{~L})_{2}\right]-$ $\left(\mathrm{ClO}_{4}\right)_{2}(\mathbf{1})$ with a tridentate ligand $(\mathrm{L})$ having 2-phenylimidazolyl groups in order to examine the $\mathrm{Fe}_{2} / \mathrm{O}_{2}$-mediated arene hydroxylation (Fig. 1). In this paper, we report on the crystal structure of $\mathbf{1}$ together with the reactivity toward dioxygen.

The tridentate ligand $\mathrm{L} \cdot \mathrm{H}_{2} \mathrm{O}$ was synthesized according to a literature method. ${ }^{7}$ The diiron(II) complex with $\mathrm{L}$ was prepared under a $\mathrm{N}_{2}$ atmosphere. A mixture of $\mathrm{Fe}\left(\mathrm{CF}_{3} \mathrm{SO}_{3}\right)_{2} \cdot 2 \mathrm{CH}_{3} \mathrm{CN}^{8}$ $(0.436 \mathrm{~g}, 1.0 \mathrm{mmol})$ and $\mathrm{L} \cdot \mathrm{H}_{2} \mathrm{O}(0.456 \mathrm{~g}, 1.0 \mathrm{mmol})$ in dry$\mathrm{THF} / \mathrm{CH}_{2} \mathrm{Cl}_{2}(1: 1,20 \mathrm{~mL})$ was added a THF solution $(3 \mathrm{~mL})$ containing $\mathrm{H}_{2} \mathrm{O}(18 \mu \mathrm{L}, 1.0 \mathrm{mmol})$ and triethylamine $(138 \mu \mathrm{L}$, $1.0 \mathrm{mmol})$ to give a yellow-green solution. Diethyl ether $(20 \mathrm{~mL})$ was added to the resulting yellow-green solution to give a yellow-green powder, which was filtered and washed with diethyl ether. Yield: 0.32 g, 47\%. Anal. Found: C, 52.51; $\mathrm{H}, 4.43 ; \mathrm{N}, 10.18 \%$. Calcd for $\left[\mathrm{Fe}_{2}(\mathrm{OH})_{2}(\mathrm{~L})_{2}\right]\left(\mathrm{CF}_{3} \mathrm{SO}_{3}\right)_{2} \cdot 2 \mathrm{H}_{2} \mathrm{O}$, $\mathrm{C}_{60} \mathrm{H}_{64} \mathrm{~F}_{6} \mathrm{Fe}_{2} \mathrm{~N}_{10} \mathrm{O}_{10} \mathrm{~S}_{2}:$ C, 52.41; H, 4.69; N, 10.19\%. Single crystals of $\left[\mathrm{Fe}_{2}(\mathrm{OH})_{2}(\mathrm{~L})_{2}\right]\left(\mathrm{ClO}_{4}\right)_{2}$ (1) suitable for X-ray crystallography were obtained by slow diffusion of diethyl ether onto a dry- $\mathrm{CH}_{2} \mathrm{Cl}_{2} / \mathrm{MeCN}$ (1:1) solution of a yellow-green powder containing $(n-\mathrm{Bu})_{4} \mathrm{NClO}_{4}$.

$\mathrm{X}$-ray diffraction measurements were made on a Rigaku CCD Mercury diffractometer with graphite-monochromated Mo $K \alpha$ radiation at $123 \mathrm{~K}$. The structure was solved by a direct method (SHELXS 97) ${ }^{9}$ and expanded using a Fourier technique. The

† To whom correspondence should be addressed.

E-mail: h-furutachi@se.kanazawa-u.ac.jp structure was refined by a full-matrix least-squares method by using a SHELXL $2014^{10}$ (Yadokari-XG). ${ }^{11}$ All non-hydrogen atoms were refined with anisotropic displacement parameters. The $\mu$-hydroxo hydrogen atoms were refined using distance restraints with $U_{\text {iso }}$ constrained to 1.2-times the $U_{\text {eq }}$ of the parent oxygen atoms. Other hydrogen atoms were included using a riding model. The crystal data are summarized in Table 1 .

$\mathrm{X}$-ray crystallography of $\mathbf{1}$ reveals that the asymmetric unit contains a half of the complex cation $\left[\mathrm{Fe}_{2}(\mathrm{OH})_{2}(\mathrm{~L})_{2}\right]^{2+}$ and a perchlorate anion. The molecular structure of the complex cation $\left[\mathrm{Fe}_{2}(\mathrm{OH})_{2}(\mathrm{~L})_{2}\right]^{2+}$ of $\mathbf{1}$ is shown in Fig. 2. Selected bond distances $(\AA)$ and angles $\left({ }^{\circ}\right)$ are given in Table 2. The complex cation $\left[\mathrm{Fe}_{2}(\mathrm{OH})_{2}(\mathrm{~L})_{2}\right]^{2+}$ of $\mathbf{1}$ has a centrosymmetric bis $(\mu-$ hydroxo)diiron(II) diamond core, as found for a closely related five-coordinated bis $(\mu$-hydroxo $)$ diiron(II) complex $\left[\mathrm{Fe}_{2}(\mathrm{OH})_{2}-\right.$

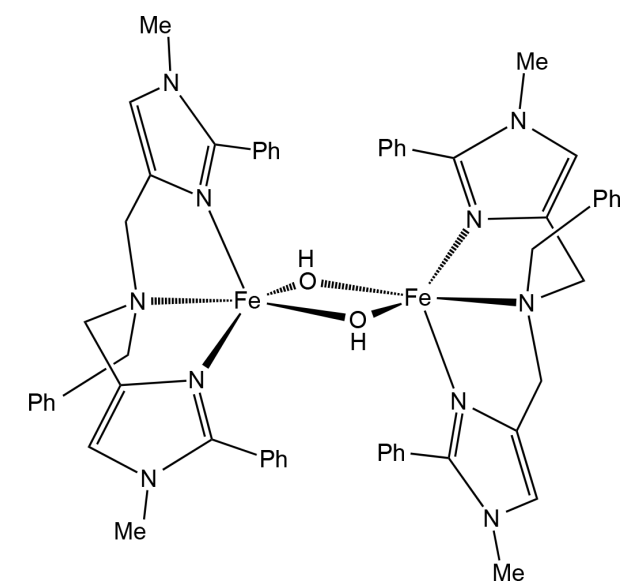

Fig. 1 Chemical diagram of the complex cation $\left[\mathrm{Fe}_{2}(\mathrm{OH})_{2}(\mathrm{~L})_{2}\right]^{2+}$ of $\mathbf{1}$. 
Table 1 Crystal and experimental data

Chemical formula: $\mathrm{C}_{58} \mathrm{H}_{60} \mathrm{Cl}_{2} \mathrm{Fe}_{2} \mathrm{~N}_{10} \mathrm{O}_{10}$

Formula weight $=1239.76$

$T=123 \mathrm{~K}$

Crystal system: triclinic

Space group: $P \overline{1}$

$a=11.007(2) \AA$

$b=11.5591(12) \AA$

$c=12.534(2) \AA$

$V=1400.4(4) \AA^{3}$

$D_{\mathrm{x}}=1.470 \mathrm{~g} / \mathrm{cm}^{3}$

Radiation: Mo $K \alpha(\lambda=0.71073 \AA)$

$\mu($ Mo $K \alpha)=6.83 \mathrm{~cm}^{-1}$

$F\left(\begin{array}{lll}0 & 0 & 0\end{array}\right)=644$

Crystal size $=0.25 \times 0.20 \times 0.08 \mathrm{~mm}^{3}$

No. of reflections collected $=15351$

No. of independent reflections $=6735$

$\theta$ range for data collection $=2.647$ to $30.519^{\circ}$

Data/Restraints/Parameters $=6735 / 1 / 375$

Goodness-of-fit on $F^{2}=1.046$

$R$ indices $[I>\sigma(I)]: R 1=0.0328, w R 2=0.0847$

$R$ indices (all data): $R 1=0.0349, w R 2=0.0862$

$(\Delta / \sigma)_{\max }=0.001$

$(\Delta \rho)_{\max }=0.339 \mathrm{e}^{-3} \quad(\Delta \rho)_{\min }=-0.481 \mathrm{e}^{-3}$

Measurement: Rigaku CCD Mercury Diffractometer

Data collection \& cell refinement program: CrystalClear

Structure solving program: SHELXS 97

Structure determination: SHELXL 2014

Refinement: full-matrix least squares against $F^{2}$

CCDC deposition number: 1887314

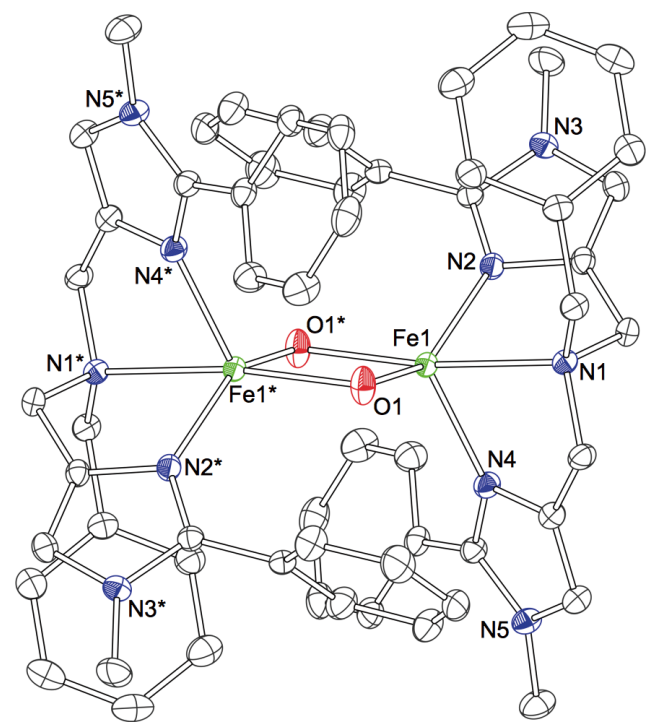

Fig. 2 ORTEP drawing of the complex cation $\left[\mathrm{Fe}_{2}(\mathrm{OH})_{2}(\mathrm{~L})_{2}\right]^{2+}$ of $\mathbf{1}$, showing $50 \%$ probability ellipsoids. The hydrogen atoms are omitted for clarity.

$\left.\left(\mathrm{HB}\left(3,5-i \mathrm{Pr}_{2} \mathrm{Pz}\right)_{3}\right)_{2}\right]$ with a tridentate ligand $\left(\mathrm{HB}\left(3,5-i \mathrm{Pr}_{2} \mathrm{Pz}\right)_{3}=\right.$ hydrotris(3,5-diisopropylpyrazol-1-yl)-borate). ${ }^{12}$ Both of the iron atoms in $\mathbf{1}$ have a distorted five-coordinate structure that is intermediate between a trigonal bipyramid and a square-pyramid $(\tau=0.44)^{13}$ with an $\mathrm{N}_{3} \mathrm{O}_{2}$ donor set, where three nitrogen atoms of $\mathrm{L}$ are in a facial array. The structural distortion around the iron atoms is much larger than that observed in $\left[\mathrm{Fe}_{2}(\mathrm{OH})_{2}(\mathrm{HB}(3,5-\right.$ $\left.\left.\left.i \operatorname{Pr}_{2} \mathrm{Pz}\right)_{3}\right)_{2}\right] \quad(\tau=0.003)$, which is probably due to unfavorable steric interactions among 2-phenylimizazolyl groups of the tridentate ligands. The $\mathrm{Fe}-\mathrm{OH}$ bond trans to the imidazole
Table 2 Selected bond distances $(\AA)$ and angles $\left({ }^{\circ}\right)$

\begin{tabular}{lrlr} 
Fe1-O1 & $1.9807(11)$ & Fe1-O1* & $2.0394(12)$ \\
Fe1-N1 & $2.2971(12)$ & Fe1-N2 & $2.0916(12)$ \\
Fe1-N4 & $2.1076(12)$ & Fe1-..Fe1* & $3.0488(9)$ \\
& & & \\
O1-Fe1-O1* & $81.36(5)$ & O1-Fe1-N1 & $93.00(5)$ \\
O1-Fe1-N2 & $142.82(5)$ & O1-Fe1-N4 & $109.61(5)$ \\
O1*-Fe1-N1 & $169.40(4)$ & O1*-Fe1-N2 & $100.53(5)$ \\
O1*-Fe1-N4 & $114.06(5)$ & N1-Fe1-N2 & $78.53(5)$ \\
N1-Fe1-N4 & $76.25(5)$ & N2-Fe1-N4 & $103.44(5)$ \\
Fe1-O1-Fe1* & $98.64(5)$ & & \\
\hline
\end{tabular}

Symmetry operation $*:-x,-y+1,-z+1$.

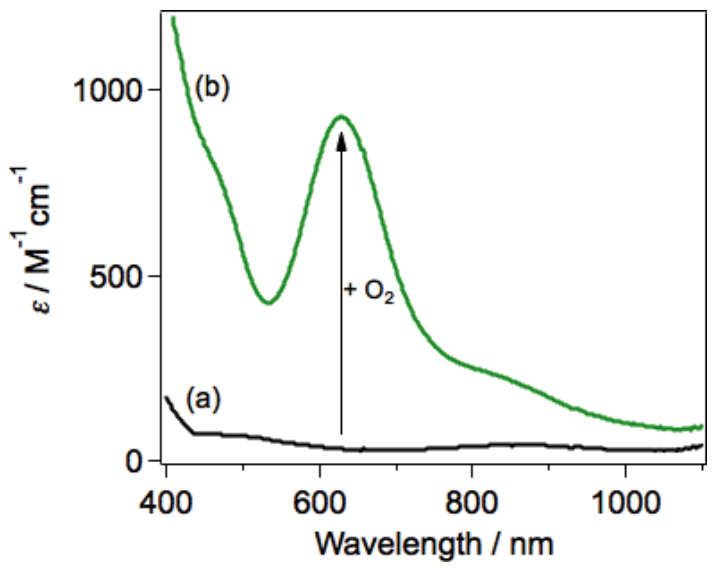

Fig. 3 Electronic spectra of (a) $\left[\mathrm{Fe}_{2}(\mathrm{OH})_{2}(\mathrm{~L})_{2}\right]\left(\mathrm{ClO}_{4}\right)_{2}(\mathbf{1})$ and (b) $\left[\mathrm{Fe}_{2}(\mathrm{O})\left(\mathrm{O}_{2}\right)(\mathrm{L})_{2}\right]^{2+}(\mathbf{2})$ generated by the reaction of 1 with $\mathrm{O}_{2}$ in $\mathrm{CH}_{2} \mathrm{Cl}_{2} / \mathrm{MeCN}(3: 1)$ at $-80^{\circ} \mathrm{C}$.

nitrogen (Fe1-O1: 1.9807(11) $)$ is slightly shorter than the corresponding bond trans to the amino nitrogen (Fe1-O1*: 2.0394(12) $\mathrm{A})$, giving rise to a slightly asymmetric diamond core $(\Delta r=0.06 \AA)$. Unlike 1 , the $\mathrm{Fe}-\mathrm{OH}$ bonds are almost equivalent in $\left[\mathrm{Fe}_{2}(\mathrm{OH})_{2}\left(\mathrm{HB}\left(3,5-i \mathrm{Pr}_{2} \mathrm{Pz}\right)_{3}\right)_{2}\right](2.04$ and $2.016 \AA ; \Delta r=0.02 \AA)$ with the capping ligand having identical donor atoms. The average $\mathrm{Fe}-\mathrm{OH}$ bond distance $(2.01 \AA)$ of $\mathbf{1}$ is comparable to those in five-coordinated bis( $\mu$-hydroxo)diiron(II) complexes $(2.00-2.03 \AA), 5,12$ but is slightly shorter than those in sixcoordinated bis $(\mu$-hydroxo)diiron(II) complexes (2.04 - $2.08 \AA){ }^{14,15}$ The $\mathrm{Fe}-. . \mathrm{Fe}$ separation is 3.0488(9) $\AA$, which is on the short side of the range reported for related bis( $\mu$-hydroxo)diiron(II) complexes $(3.010$ - $3.187 \AA$ A $) .5,12,14,15$ The Fe-OH bond distances as well as the $\mathrm{Fe}-\mathrm{O}-\mathrm{Fe}$ and $\mathrm{O}-\mathrm{Fe}-\mathrm{O}$ angles are in the range of those observed for related bis( $\mu$-hydroxo)diiron(III) complexes. The Fe-ligand bond distances observed for 1 are consistent with the complexes having high spin $\mathrm{Fe}(\mathrm{II})$ ions. ${ }^{4,5,12,14,15}$

The reaction of 1 with $\mathrm{O}_{2}$ in $\mathrm{CH}_{2} \mathrm{Cl}_{2} / \mathrm{MeCN}(3: 1)$ at $-80^{\circ} \mathrm{C}$ generated a dark-green peroxo species (2), which exhibits an intense absorption band at $630 \mathrm{~nm}\left(\varepsilon=930 \mathrm{M}^{-1} \mathrm{~cm}^{-1}\right)$ that can be assigned to the CT transition from $\mathrm{O}_{2}{ }^{2-}$ to $\mathrm{Fe}$ (III) center, ${ }^{3}$ together with bands at $\sim 460 \mathrm{~nm}\left(\mathrm{sh}, \varepsilon=810 \mathrm{M}^{-1} \mathrm{~cm}^{-1}\right)$ and $\sim 825 \mathrm{~nm}\left(\varepsilon=235 \mathrm{M}^{-1} \mathrm{~cm}^{-1}\right)$ (Fig. 3). The spectral feature of 2 is quite similar to those of well-characterized ( $\mu$-oxo)( $\mu$-peroxo)diiron(III) complexes. ${ }^{3,14-16}$ The resonance Raman (rR) spectra of 2 showed two isotope-sensitive bands at $839 \mathrm{~cm}^{-1}\left({ }^{16-18} \Delta=\right.$ $\left.49 \mathrm{~cm}^{-1}\right)$ and $486 \mathrm{~cm}^{-1}\left({ }^{16-18} \Delta=22 \mathrm{~cm}^{-1}\right)$ in $\mathrm{CH}_{2} \mathrm{Cl}_{2} / \mathrm{MeCN}(3: 1)$ at $-80^{\circ} \mathrm{C}$ with a $607-\mathrm{nm}$ laser excitation (Fig. S1). These bands can be assigned to $v(\mathrm{O}-\mathrm{O})$ and $v_{\mathrm{s}}(\mathrm{Fe}-\mathrm{O})$ vibrations, respectively, 
which are also similar to those of well-characterized ( $\mu$-охо) ( $\mu$-peroxo)diiron(III) complexes. ${ }^{3,14-16}$ Thus, these data indicate that 2 has a $(\mu$-oxo $)(\mu$-peroxo)diiron(III) core (Scheme S1).

Peroxo species $\left[\mathrm{Fe}_{2}(\mathrm{O})\left(\mathrm{O}_{2}\right)(\mathrm{L})_{2}\right]^{2+}(2)$ gradually decomposes in $\mathrm{CH}_{2} \mathrm{Cl}_{2} / \mathrm{MeCN}(3: 1)$ at $-80^{\circ} \mathrm{C}$, but quickly decays at $-60^{\circ} \mathrm{C}$. The decomposition of $\mathbf{2}$ obeys first-order kinetics (Fig. S2), where the $k_{\mathrm{d}}$ value (first-order rate constant of selfdecomposition) is $1.2 \times 10^{-3} \mathrm{~s}^{-1}$. However, 2 showed no intramolecular aromatic ligand hydroxylation (Scheme S1). This result is in sharp contrast to the intramolecular aromatic ligand hydroxylation initiated by ( $\mu$-peroxo)diiron(III) complexes with dinucleating ligands. ${ }^{4-6}$ The origin of such a difference is not clear at the present time. For a fuller understanding of such different reactivity, further comprehensive functional model studies are needed.

\section{Acknowledgements}

This work was supported by Grants-in-Aid for Scientific Research from the Ministry of Education, Culture, Sports, Science and Technology, Japan, and the Kanazawa University SAKIGAKE Project.

\section{Supporting Information}

A cif format file, Figs. S1 and S2, and Scheme S1. These materials are available free of charge on the Web at http://www. jsac.or.jp/xraystruct/.

\section{References}

1. M. H. Sazinsky and S. J. Lippard, Acc. Chem. Res., 2006, 39, 558 .

2. J. F. Acheson, L. J. Bailey, T. C. Blunold, and B. G. Fox,
Nature, 2017, 544, 191

3. A. J. Jasniewski and L. Que Jr., Chem. Rev., 2018, 118, 2554.

4. M. Yamashita, H. Furutachi, T. Tosha, S. Fujinami, W. Saito, Y. Maeda, K. Takahashi, K. Tanaka, T. Kitagawa, and M. Suzuki, J. Am. Chem. Soc., 2007, 129, 2.

5. M. Sekino, H. Furutachi, K. Tasaki, T. Ishikawa, S. Mori, S. Fujinami, S. Akine, Y. Sakata, T. Nomura, T. Ogura, T. Kitagawa, and M. Suzuki, Dalton Trans., 2016, 45, 469.

6. M. Sekino, H. Furutachi, R. Tojo, A. Hishi, H. Kajikawa, T. Suzuki, K. Suzuki, S. Fujinami, S. Akine, Y. Sakata, T. Ohta, S. Hayami, and M. Suzuki, Chem. Commun., 2017, 53,8838 .

7. K. Itoh, H. Hayashi, H. Furutachi, T. Matsumoto, S. Nagatomo, T. Tosha, S. Terada, S. Fujinami, M. Suzuki, and T. Kitagawa, J. Am. Chem. Soc., 2005, 127, 5212.

8. K. S. Hagen, Inorg. Chem., 2000, 39, 5867.

9. G. M. Sheldrick, SHELXS-97, Program for the Solution of Crystal Structures, University of Göttingen, Germany, 1997.

10. G. M. Sheldrick, Acta. Crystallogr., 2008, A64, 112.

11. C. Kabuto, S. Akine, T.Nemoto, and E. Kwon, J. Cryst. Soc. Jpn., 2009, 51, 218.

12. N. Kitajima, N. Tamura, M. Tanaka, and Y. Moro-oka, Inorg. Chem., 1992, 31, 3342.

13. A. W. Addison, T. N. Rao, J. Reedijk, J. van. Rijn, and G. C. Verschoor, J. Chem. Soc., Dalton Trans., 1984, 1349.

14. V. L. MacMurdo, H. Zheng, and L. Que Jr., Inorg. Chem., 2000, 39, 2254.

15. S. V. Kryatov, S. Taktak, I. V. Korendovych, E. V. RybakAkimova, J. Kaizer, S. Torelli, X. Shan, S. Mandal, V. L. MacMurdo, A. M. i. Payeras, and L. Que Jr., Inorg. Chem., 2005, 44, 85 .

16. X. Zhang, H. Furutachi, S. Fujinami, S. Nagatomo, Y. Maeda, Y. Watanabe, T. Kitagawa, and M. Suzuki, J. Am. Chem. Soc., 2005, 127, 826. 